\title{
Physicochemical properties of powdered, soft and hard type rice flour by different milling methods
}

\author{
Ok Ja Choi, Hee Nam Jung, Ki Hoon Shim* \\ Department of Food and Cooking Science, Sunchon National University, Suncheon 540-950, Korea
}

\section{제분방법에 따른 분질, 연질 및 경질미 가루의 이화학적 특성}

\author{
최옥자·정희남·심기훈* \\ 순천대학교 조리과학과
}

\begin{abstract}
This study investigated the physicochemical properties of three different types of rice flour prepared via dry and wet milling. The powder, soft, and hard-types of rice flour were Suwon No. 542, Suwon No. 541, and Unbong No. 30, respectively. The analysis of the proximate compositions of the different types of rice flour showed that their moisture content was $7.03 \sim 7.99 \%$, their crude protein was $7.94 \sim 8.35 \%$, their crude lipid was $0.71 \sim 1.49 \%$ and their crude ash was $0.25 \sim 0.82 \%$. For the Hunter's color values, the $L$ value was highest in the wet-milled rice flour, the a value was highest in the dry-milled rice flour, and the b value was highest in the dry-milled rice flour. All the samples showed distinctive rice starch particles in the particle analysis using scanning electron microscope. The dry-milled rice flour showed the greatest amount of irregular particles and the coarsest texture. The water absorption and water solubility indices were higher in the wet-milled soft- and hard-type rice flour. The crystallinities of the samples by X-ray diffractography were all A-type, but the crystallinity of the dry-milled hard-type rice flour was higher in diffraction degree. For the amylogram properties, the wet-milled soft-type rice flour showed the highest maximum viscosity, breakdown and setback. In the meanwhile, the dry-milled soft-type rice flour showed the highest initial pasting temperature, onset, peak, and end temperatures despite of the reverse enthalpy.
\end{abstract}

Key words : rice flour, milling method, physicochemical properties

\section{서 론}

쌀은 예전부터 주식으로 이용되어왔지만 국민소득의 향 상과 생활패턴의 서구화, 간편화 및 다양화 등으로 인하여 주식의 주 소비 형태인 밥 대신에 밀가루를 이용한 식품의 소비가 증가하고 있다 $(1,2)$. 또한, 농산물 시장 개방 및 쌀 수입이 확대됨에 따라 수입쌀이 밥쌀용으로 시판되고, 국 내 벼 재배면적의 감소와 1 인당 쌀 소비량 감소가 지속되고

*Corresponding author. E-mail : khshim@sunchon.ac.kr Phone : 82-61-750-3697, Fax : 82-61-750-3690

Received 24 December 2014; Revised 29 March 2015; Accepted 31 March 2015.

Copyright (c) The Korean Society of Food Preservation. All rights reserved.
있어 국내 쌀의 산업 여건은 더욱 악화되고 있는 실정이다 (3). 1970년대 통일벼의 미질과 내냉성 등의 단점을 보완하 기 위한 연구를 비롯하여, 최근에는 기능성을 갖고 있는 특수미나 고품질 쌀에 관련된 연구가 중점적으로 진행되어 가공용 찰벼, 중간찰벼, 유색벼, 기능성 강화벼, 향미벼, 가 공용, 초다수 및 사료용 품종 등이 개발되었다(3-5)

이러한 다양한 쌀 품종 개발 연구로 인하여 국내 쌀 관련 산업은 과거 주류, 떡류, 면류에 한정적이었던 부분에서 최근 밥류 및 죽류 산업이 확대되고 있고, 과자류, 음료류 및 조미식품에서도 쌀을 이용한 제품이 개발되고 있다(6). 쌀은 가공식품 개발의 원료로서 다양하게 활용을 하고 있으 나, 쌀을 가공식품의 소재로서 활용도를 더 높이기 위해서 는 운반, 보관 및 사용이 편리한 가루형태로의 공급이 필요 하며(1), 가공적성에 맞는 쌀가루 생산을 위한 품종개량, 
제분방법 및 가공기술에 대한 지속적인 연구가 필요하고 하겠다(7).

쌀가루의 활용도를 높이기 위한 제분방법에 대한 연구는 지속적으로 진행되어 쌀가루의 품질은 습식제분과 건식제 분 방법에 따라 품질의 크게 영향을 받는 것으로 알려져 있다(8-10). 습식제분 방법으로 쌀가루를 제조하면 수침과 정에서 수분이 흡수되어 경도가 감소하고 일반성분이 용출 되며, 수침시간과 온도에 따라 가공적성이 차이가 있다 (11-15). 수침과정은 쌀가루의 품질특성에 영향을 미치기 때문에 습식제분 방법으로 제조된 쌀가루는 건식제분 방법 으로 제조된 쌀가루와 서로 다른 호화특성을 보인다(1). 건식제분 방법으로 제조된 쌀가루는 손상된 전분의 양이 많아지고, 제조 과정 중에 열이 발생하여 쌀 가공제품에 사용되는 쌀가루로 적합하지 않은 것으로 알려져 있다(16). 이렇듯 각각의 제분방법에 따라 제조된 쌀가루의 입자는 최종 제품의 조직감에 영향을 주기 때문에 제분한 가루의 특성에 대한 연구가 필요하다. 따라서 본 연구에서는 쌀가 루의 활용도를 높이고, 쌀 가공 관련 산업의 활성을 위하여 분질미, 연질미, 경질미 품종을 습식제분 및 건제제분 방법 으로 쌀가루를 제조하여 각각의 호화 특성을 분석하여 기초 자료로 활용하고자 하였다.

\section{재료 및 방법}

\section{재 료}

본 실험에서 사용한 쌀은 2013년에 수확한 분질미(수원 542호), 연질미(수원 541호), 경질미(운봉 30호)로 전남농업 기술원으로부터 제공 받았으며, 백미로 도정하여 사용하였 다.

\section{쌀가루 제조}

본 실험에 사용한 건식제분 쌀가루는 기류식 초미분쇄기 (Dream Mill DM-150S, Furukawa, Tokyo, Japan)로 200 mesh 분쇄하여 시료로 사용하였고, 습식제분 쌀가루에서 분질미 는 1 시간, 연질미는 2 시간, 경질미는 4 시간 각각 수침시켜 중심부까지 수분포화 시킨 후 roll mill(HMF-100, Hanil Electric Co., Korea)로 2회 분쇄한 후 건조하여 다시 기류식 초미분쇄기(Dream Mill DM-150S, Furukawa, Tokyo, Japan) 로 $200 \mathrm{mesh}$ 분쇄하여 시료로 사용하였다.

\section{일반성분 측정}

쌀가루의 일반성분 분석은 $\mathrm{AOAC}$ 법(17)에 따라 분석하 였다. 수분은 상압가열건조법, 조단백질은 Kjeldahl법, 조지 방은 Soxhlet법 그리고 조회분은 직접회화법으로 각각 3회 반복 측정하였다.
색도 측정

쌀가루의 색도는 색차계(JC 801S, Color Techno System Co., Tokyo, Japan)를 사용하여 L값, a값, b값을 6회 반복 측정하였다.

\section{주사전자현미경을 이용한 입자의 형태 관찰}

쌀가루의 입자형태 관찰은 주사전자현미경(JSM-5400, JEOL Ltd., Tokyo, Japan)을 사용하여 가속전압 $25 \mathrm{kV}$, phototimes 85 초의 조건에서 5,000배의 배율로 입자 형태를 관찰하였다.

\section{수분흡수지수 및 수분용해지수 측정}

쌀가루의 수분흡수지수(water absorbtion index, WAI)와 수분용해지수(water solubility index, WSI)는 Anderson 등 (18)의 방법을 변형하여 3회 반복 측정하였다. 수분흡수지 수는 쌀가루 $3 \mathrm{~g}$ 과 증류수 $30 \mathrm{~mL}$ 를 원심분리관에 넣고 30 분간 진탕 교반한 후 원심분리기를 이용하여 $3,000 \mathrm{rpm}$ 에 서 20 분간 원심분리 하였다. 상등액을 제외한 침전물의 무 게를 평량하여 건조시료 $\mathrm{g}$ 당 흡수된 수분함량으로 표시하 였다.

$$
\text { WAI }=\frac{\text { Hydrated sample wt. }- \text { Dry sample wt. }}{\text { Dry sample wt. }}
$$

수분용해지수는 수분흡착지수 측정 시 회수한 상등액을 증발접시에 옮긴 후, 건조온도 $105^{\circ} \mathrm{C}$ 의 열풍건조기에서 건 조시켜 얻어진 고형분의 무게를 건조시료에 대한 백분율로 나타내었다.

$$
\mathrm{WSI}(\%)=\frac{\text { Dry solid wt. recovered by evaporating the supernatant }}{\text { Dry sample wt. }} \times 100
$$

\section{$X-$ 선 회절도 측정}

쌀가루의 결정성은 X-선 회절기(D-MAX-1200, Rigaku Co., Ltd., Tokyo, Japan)를 사용하여 target: $\mathrm{Cu}-\mathrm{Ka}$, filter: $\mathrm{Ni}$, voltage: $35 \mathrm{KV}$, current: $15 \mathrm{~mA}$, time constant: $1 \mathrm{sec}$, F.S.R:

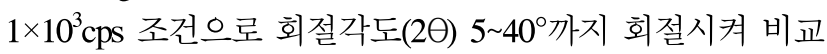
하였다.

\section{Amylogram에 의한 호화 특성 분석}

쌀가루의 호화특성은 Micro/Visco/Amylograph(Brabender Measurement \& Control System, Duisburg, Germany)를 사용 하여 Medcalf와 Gilles(19)의 방법에 따라 5회 반복 측정하 였다. 쌀가루 $10 \%$ 현탁액을 $100 \mathrm{~mL}$ 의 용기에 넣은 다음 $30^{\circ} \mathrm{C}$ 에서 10 분간 교반한 후, 가열속도 $5.0^{\circ} \mathrm{C} / \mathrm{min}$, 회전속도 $250 \mathrm{rpm}$ 조건으로 $95^{\circ} \mathrm{C}$ 까지 가열하고 15 분간 교반한 후, 
$5.0^{\circ} \mathrm{C} / \mathrm{min}$ 속도로 $50^{\circ} \mathrm{C}$ 까지 냉각하였다. 이와 같이 얻은 amylogram으로부터 호화개시온도, 최고점도, 최저점도 등 amylogram 특성 값을 구하였다. 호화개시온도는 점도가 10 Brabender Units(B.U.)에 도달한 온도로 나타냈다.

\section{시차열량주사계의 의한 호화 특성 측정}

시차열 량주사계(Jade DSC, PerkinElmer, Co., Ltd., MA, USA)를 이용한 호화엔탈피 분석은 Donovan 등(20)의 방법 에 따라 쌀가루 $3.0 \mathrm{mg}$ 을 aluminum bath에 취하고 여기에 3 배의 증류수를 microsylinge로 가하여 밀봉한 다음 30 분간 방치한 후 시차열량주사계(differential scanning calorimetry: $\mathrm{DSC}$ )를 사용하여 $30^{\circ} \mathrm{C}$ 에서 $95^{\circ} \mathrm{C}$ 까지 $10^{\circ} \mathrm{C} / \mathrm{min}$ 속도로 가열 하여 흡열(endothermic) peak를 얻었다. 이 peak로부터 호화 개시온도(onset temperature, To), 호화정점온도(peak temperature, $\mathrm{Tp}$ ), 호화종료온도(conclusion temperature, $\mathrm{Tc}$ ) 및 호화엔탈피 (gelatinization enthalpy, $\Delta \mathrm{H}$ )를 5 회 반복 측정하여 구하였다.

\section{통계처리방법}

실험결과는 SPSS 프로그램을 이용하여 일원배치 분산분 석(ANOVA)으로 통계처리 하였으며, $\mathrm{p}<0.05$ 수준에서 Duncan's multiple range test를 실시하여 시료간의 유의적인 차이를 검증하였다.

\section{결과 및 고찰}

\section{일반성분}

건식 및 습식제분한 분질, 연질, 경질미 쌀가루의 일반성 분 결과는 Table 1 과 같다. 건식제분 쌀가루의 수분함량은 7.68 7.99\%, 습식제분 쌀가루는 7.03 7.57\%로 나타났고, 건식제분 연질미의 쌀가루의 수분함량이 $7.99 \%$ 로 가장 높 았고, 습식제분한 분질미 쌀가루의 수분함량이 $7.03 \%$ 로 가장 낮았으며, 시료간에 유의한 차이가 있었다. 조단백 함량은 건식제분 쌀가루에서 7.96 8.35\%로 나타났고, 습식 제분 쌀가루에서 7.94 8.12\%로 나타났으며, 건식제분 분질 미 쌀가루가 $8.35 \%$ 로 가장 높았고, 습식제분 경질미 쌀가루 가 $7.94 \%$ 로 가장 낮았으며, 시료간에 유의한 차이가 있었 다. 조지방 함량은 건식제분 쌀가루에서 $1.32 ~ 1.49 \%$ 로 나 타났고, 습식제분 쌀가루에서 $0.71 ~ 0.99 \%$ 로 건식제분 경질 미 쌀가루가 $1.49 \%$ 로 가장 높았고, 습식제분 연질미 쌀가루 는 $0.71 \%$ 로 가장 낮았으며, 시료간에 유의한 차이가 있었 다. 조회분 함량은 건식제분 쌀가루에서 $0.71 ~ 0.82 \%$ 로 나 타났고, 습식제분 쌀가루에서 $0.25 ~ 0.31 \%$ 로 건식제분 경질 미 쌀가루가 $0.82 \%$ 로 가장 높았고, 습식제분 분질미 쌀가루 는 $0.25 \%$ 로 가장 낮았으며, 시료간에 유의한 차이가 있었 다. 각각의 시료는 건식제분 쌀가루의 일반성분이 습식제 분 쌀가루의 일반성분보다 높게 나타났으며, 이와 같은 결
과는 Lee와 Shin(21)의 수침과 입자크기를 달리한 쌀가루 특성 연구에서도 유사한 결과가 나타났는데 이는 쌀 내부의 수용성 물질이 용출된 것으로 수침과정에서 물이 침투해서 나타난 결과라고 보고하였다. 또한, 다른 연구(13,15,22-25) 에서도 쌀 제분시 수침과정을 거치면 수용성 단백질 및 지방 물질이 용출되고, 쌀의 수침시간이 길어질수록 조단 백 및 조회분 함량은 감소한다고 하였다.

Table 1. Proximate compositions of the different types of rice flour using different grinding methods

(Unit: \%)

\begin{tabular}{|c|c|c|c|c|c|}
\hline & amples & Moisture & Crude protein & Crude lipid & Crude ash \\
\hline \multirow{3}{*}{$\begin{array}{l}\text { Dry milled } \\
\text { rice }\end{array}$} & & $7.68 \pm 0.06^{b 1)}$ & $8.35 \pm 0.11^{\mathrm{a}}$ & $1.48 \pm 0.01^{\mathrm{a}}$ & $0.71 \pm 0.01^{\mathrm{c}}$ \\
\hline & Soft type & $7.99 \pm 0.08^{\mathrm{a}}$ & $8.03 \pm 0.16^{b}$ & $1.32 \pm 0.03^{b}$ & $0.77 \pm 0.03^{b}$ \\
\hline & & $7.92 \pm 0.13^{\mathrm{a}}$ & $7.96 \pm 0.16^{b}$ & $1.49 \pm 0.03^{\mathrm{a}}$ & $0.82 \pm 0.01^{\mathrm{a}}$ \\
\hline \multirow{3}{*}{$\begin{array}{l}\text { Wet milled } \\
\text { rice }\end{array}$} & & $7.03 \pm 0.07^{\mathrm{d}}$ & $8.12 \pm 0.07^{\mathrm{ab}}$ & $0.86 \pm 0.06^{\mathrm{d}}$ & $0.25 \pm 0.01^{\mathrm{e}}$ \\
\hline & Soft ty & $7.57 \pm 0.12^{\mathrm{bc}}$ & $7.95 \pm 0.20^{b}$ & $0.71 \pm 0.09^{e}$ & $0.29 \pm 0.03^{\mathrm{de}}$ \\
\hline & Hard type & $7.46 \pm 0.15^{\mathrm{c}}$ & $7.94 \pm 0.15^{b}$ & $0.99 \pm 0.06^{\mathrm{c}}$ & $0.31 \pm 0.04^{d}$ \\
\hline
\end{tabular}

${ }^{1)}$ All the values are mean $\pm \mathrm{SD}$, means with different superscripts in a column significantly differed $(p<0.05)$ in Duncan's multiple-range test.

색 도

건식 및 습식 제분한 분질, 연질, 경질미 쌀가루의 색도 결과는 Table 2 와 같다. $\mathrm{L}$ 값 측정 결과, 건식제분 쌀가루는 95.63 96.07로 나타났고 습식제분 쌀가루는 96.10 96.40으 로 나타나 습식제분 쌀가루의 L값이 더 높았다. 습식제분 분질미 쌀가루가 96.40 으로 가장 높게 나타났고 건식제분 연질미 쌀가루는 95.63으로 가장 낮게 나타났으며, 시료간 에 유의한 차이가 있었다. 습식제분 쌀가루의 $\mathrm{L}$ 값이 높은 것은 pin mill이나 colloid mill을 이용하여 습식제분할 경우 쌀가루의 입도가 미세하기 때문인 것으로 알려져 있으며, 미세입도 분포율이 높은 제분기를 이용할 때도 $\mathrm{L}$ 값은 높게 나타났다고 하였다 $(8,26)$. a값 측정 결과, 건식제분 쌀가루 는 - 0.53 -0.37로 나타났고 습식제분 쌀가루는-0.65 -0.40 으로 나타났다. 건식제분 분질미 쌀가루는 -0.37 로

Table 2. Hunter's color values of the different types of rice flour using different grinding methods

\begin{tabular}{|c|c|c|c|c|}
\hline & amples & $\mathrm{L}$ & $\mathrm{a}$ & $\mathrm{b}$ \\
\hline \multirow{3}{*}{$\begin{array}{l}\text { Dry milled } \\
\text { rice }\end{array}$} & Powdered type & $96.07 \pm 0.11^{\mathrm{bl})}$ & $-0.37 \pm 0.10^{\mathrm{a}}$ & $3.29 \pm 0.17^{a}$ \\
\hline & Soft type & $95.63 \pm 0.20^{\mathrm{d}}$ & $-0.51 \pm 0.14^{b}$ & $3.02 \pm 0.07^{\mathrm{b}}$ \\
\hline & Hard type & $95.82 \pm 0.09^{c}$ & $-0.53 \pm 0.07^{b}$ & $3.46 \pm 0.04^{2}$ \\
\hline \multirow{3}{*}{$\begin{array}{l}\text { Wet milled } \\
\text { rice }\end{array}$} & Powdered type & $96.40 \pm 0.08^{\mathrm{a}}$ & $-0.40 \pm 0.07^{\mathrm{a}}$ & $2.59 \pm 0.07^{\circ}$ \\
\hline & Soft type & $96.10 \pm 0.04^{\mathrm{b}}$ & $-0.58 \pm 0.06^{\mathrm{bc}}$ & $2.83 \pm 0.39^{\mathrm{b}}$ \\
\hline & Hard type & $96.26 \pm 0.09^{\mathrm{a}}$ & $-0.65 \pm 0.05^{\mathrm{c}}$ & $3.01 \pm 0.11^{b}$ \\
\hline
\end{tabular}

${ }^{1)}$ All the values are mean $\pm \mathrm{SD}$, means with different superscripts in a column significantly differed $(\mathrm{p}<0.05)$ in Duncan's multiple-range test. 
$\mathrm{a}$ 값이 가장 높았고 습식제분 경질미 쌀가루는 -0.65 로 가 장 낮게 나타났으며, 시료간에 유의한 차이가 있었다. 건식 및 습식한 쌀가루에서 쌀 입자가 단단할수록 $\mathrm{a}$ 값은 낮아지 는 경향을 보였다. $\mathrm{b}$ 값 측정 결과, 건식제분 쌀가루는 3.02 3.46으로 나타났고 습식제분 쌀가루는 2.59 3.01로 나 타났으며, 건식제분 경질미 쌀가루는 3.46 으로 가장 높았고
습식제분 분질미 쌀가루에서 2.59로 가장 낮게 나타났으며, 시료간에 유의한 차이가 있었다.

주사전자현미경을 이용한 입자의 형태

건식 및 습식 제분한 분질, 연질, 경질미 쌀가루의 주사전 자현미경을 이용한 입자의 형태는 Fig. 1과 같다. 제분성이

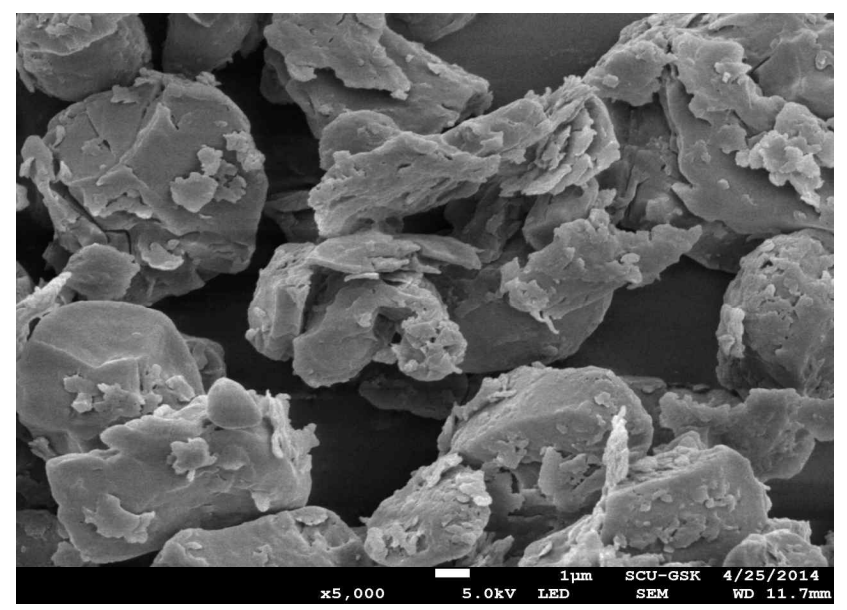

Dry milled rice-powdered type

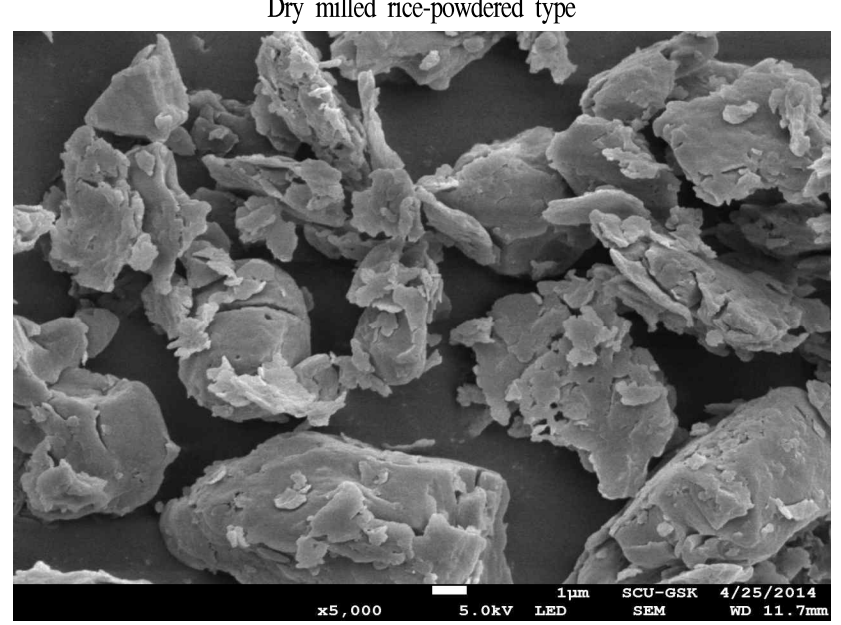

Dry milled rice-soft type

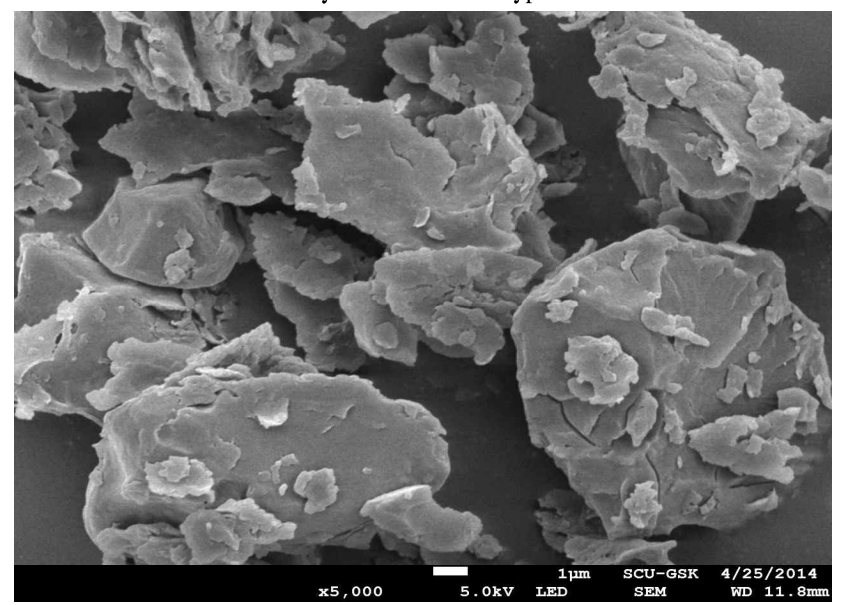

Dry milled rice-hard type

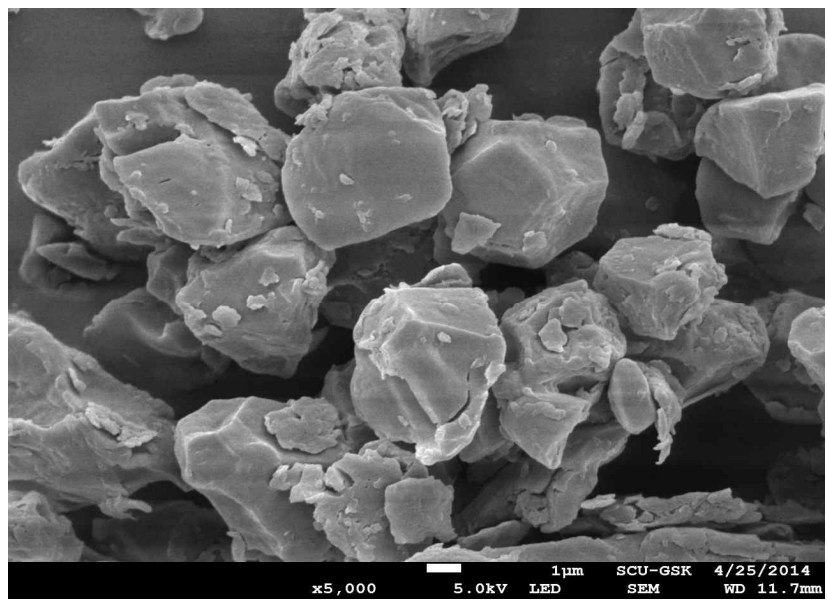

Wet milled rice-powdered type

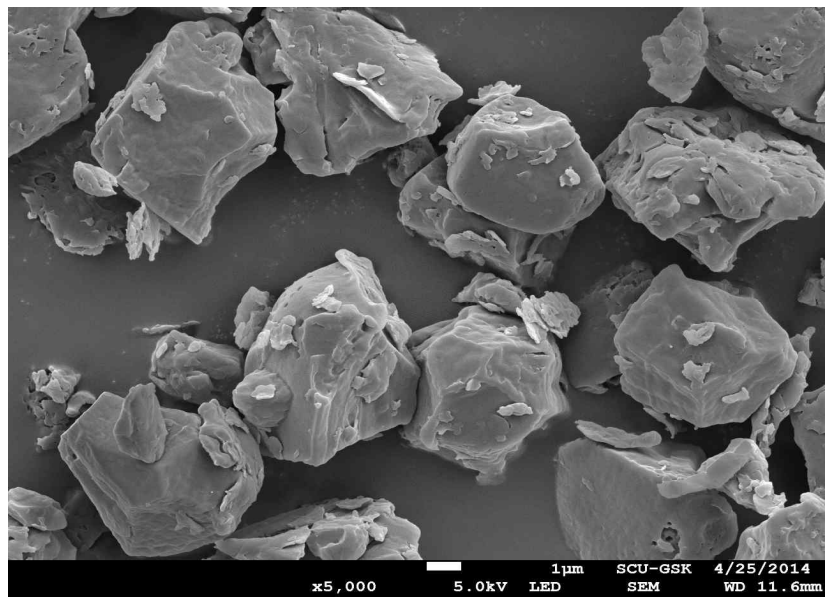

Wet milled rice-soft type

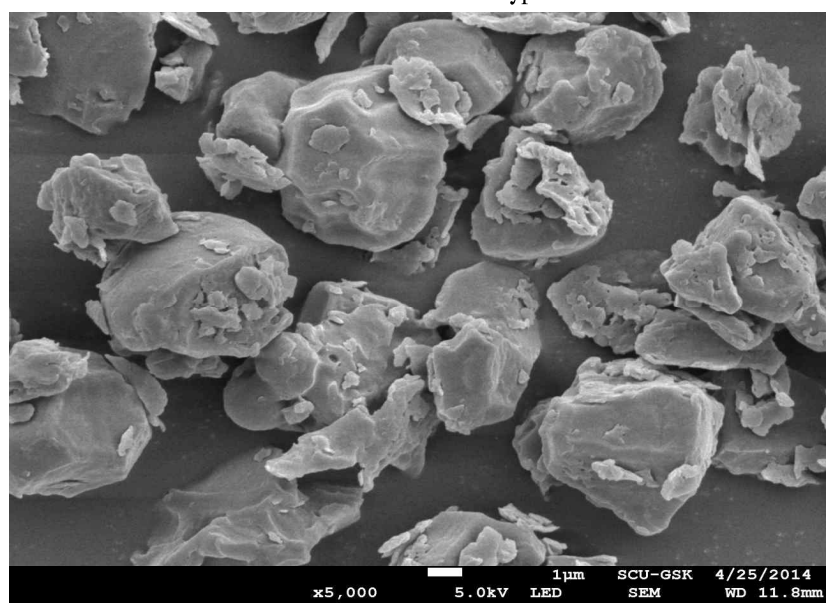

Wet milled rice-hard type

Fig. 1. Scanning electronic microphotographs of the different types of rice flour using different grinding methods. 
란 곡류 낟알의 파쇄 또는 변형에 대한 저항성을 나타내는 것으로 입자의 크기와 분포, 손상된 전분의 정도에 따라 영향을 받는 것으로 알려져 있다(27). 쌀가루 입자 형태는 다각형 형태의 쌀 전분 특유한 형태의 입자를 나타냈다. 건식제분 쌀가루의 크기는 4.32 10.08 $\mu \mathrm{m}$, 습식게분 쌀가 루의 크기는 4.89 6.79 $\mu \mathrm{m}$ 로 습식제분한 쌀가루의 입자크 기가 작게 나타났다. 건식제분 쌀가루와 습식제분 쌀가루 를 비교하면 건식제분 쌀가루의 형태가 습식제분 쌀가루 형태보다 불규칙하고 거칠며 큰 입자가 많은 것으로 나타났 다. 분질, 연질 및 경질미의 경우 제분방법에 관계없이 쌀의 입자가 단단해 질수록 작은 파편의 수가 더 증가되었다. 이는 제분시 분질미 경우 경질미보다 쉽게 가루화되기 때문 에 작은 파편이 적게 발생되는 것으로 생각된다. 특히 분질 미 쌀가루는 습식제분한 다른 쌀가루에 비해 입자의 크기와 분포가 고르고, 손상된 전분이 적게 나타나 제분성이 좋기 때문에 쌀 가공제품 제조시 다양하게 활용될 수 있을 것으 로 생각된다.

\section{수분흡수지수 및 수분용해지수}

건식 및 습식 제분한 분질, 연질, 경질미 쌀가루의 수분흡 수지수(water absorbtion index, WAI)와 수분용해지수(water solubility index, WSI)를 측정한 결과는 Table 3 과 같다. 건식 제분 쌀가루의 수분흡수지수는 1.00 1.10으로 나타났고 습 식제분 쌀가루는 1.04 1.28로 나타났다. 습식제분 연질미 와 경질미 쌀가루의 수분흡수지수가 각각 $1.28,1.27$ 로 높았 고 건식제분 분질미 쌀가루의 수분흡수지수는 1.00 으로 가 장 낮게 나타났으며, 시료간에 유의한 차이가 있었다. 건식 제분 분질미의 수분흡수지수가 낮은 것은 Table 1 의 보는바 와 것과 같이 일반성분 중 조단백 함량과 조지방 함량이 다른 시료보다 높아 전분입자와의 수분 결합을 방해한 결과 라고 할 수 있다(28). 또한 습식제분 방식이 건식제분 방식 보다 수분흡수지수가 높은 것은 Fig. 1에서 보는바와 같이 습식제분한 입자의 크기가 더 작아 물과 접촉할 수 있는 표면적이 넓어져 나타난 결과로 생각된다(21). 입자가 작은 쌀가루를 이용한 제과 및 제빵 제품의 질감이 부드러워지고

Table 3. Water absorption index and water solubility index of the different types of rice flour using different grinding methods

\begin{tabular}{cccc}
\hline & Samples & $\begin{array}{c}\text { Water absorption } \\
\text { index }\end{array}$ & $\begin{array}{c}\text { Water solubility index } \\
(\%)\end{array}$ \\
\hline \multirow{2}{*}{$\begin{array}{c}\text { Dry milled } \\
\text { rice }\end{array}$} & Powdered type & $1.00 \pm 0.01^{\mathrm{d} 1)}$ & $2.57 \pm 0.08^{\mathrm{e}}$ \\
& Soft type & $1.06 \pm 0.04^{\mathrm{bc}}$ & $3.74 \pm 0.07^{\mathrm{c}}$ \\
& Hard type & $1.10 \pm 0.04^{\mathrm{b}}$ & $5.09 \pm 0.08^{\mathrm{b}}$ \\
\multirow{4}{*}{$\begin{array}{c}\text { Wet milled } \\
\text { rice }\end{array}$} & Powdered type & $1.04 \pm 0.02^{\mathrm{cd}}$ & $2.77 \pm 0.02^{\mathrm{d}}$ \\
& Soft type & $1.28 \pm 0.03^{\mathrm{a}}$ & $5.89 \pm 0.12^{\mathrm{a}}$ \\
& Hard type & $1.27 \pm 0.01^{\mathrm{a}}$ & $5.84 \pm 0.10^{\mathrm{a}}$ \\
\hline
\end{tabular}

${ }^{11}$ All the values are mean $\pm \mathrm{SD}$, means with different superscripts in a column significantly differed $(p<0.05)$ in Duncan's multiple-range test.
부피가 증가한다고 알려져 있어(29) 다양한 쌀 가공제품 개발이 가능할 것으로 생각된다. 수분용해지수 측정결과에 서 건식제분 쌀가루는 2.57 5.09\%로 나타났고 습식제분 쌀가루는 2.77 5.89\%로 나타났다. 수분흡수지수와 마찬가 지로 습식제분 연질미와 경질미 쌀가루가 각각 $5.89,5.84 \%$ 로 가장 높았고 건식제분 분질미 쌀가루는 $2.57 \%$ 로 가장 낮았으며, 시료간에 유의한 차이가 있었다.

\section{$X-$ 선 회절도}

건식 및 습식 제분한 분질, 연질, 경질미 쌀가루의 X-선 회절도를 측정한 결과는 Fig. 2 와 같다. X-선 회절도는 전분 입자의 결정형태와 결정화도를 peak의 형태를 통해서 비교 할 수 있다. 건식제분 중에서 분질미 쌀가루의 회절각도는 $15.13^{\circ}, 17.88^{\circ}, 18.07^{\circ}, 23.03^{\circ}$ 에서 강한 peak를 나타냈고, 연질미 쌀가루의 회절각도는 $15.13^{\circ}, 17.16^{\circ}, 18.09^{\circ}, 23.11^{\circ}$ 에서 강한 peak를 나타냈으며, 경질미 쌀가루의 회절각도 는 $15.15^{\circ}, 17.94^{\circ}, 18.04^{\circ}, 23.06^{\circ}$ 에서 강한 peak를 나타냈다. 습식 제분한 분질미, 연질미 및 경질미의 회절각도는 각각 $15.13^{\circ}, 17.86^{\circ}, 18.14^{\circ}, 22.93^{\circ}$ 와 $15.18^{\circ}, 17.91^{\circ}, 18.07^{\circ}$, $23.01^{\circ}$ 그리고 $15.08^{\circ}, 17.16^{\circ}, 18.07^{\circ}, 23.03^{\circ}$ 에서 강한 peak 를 나타냈는데 모든 시료는 $3 \mathrm{~b}$ 환, $4 \mathrm{a}, 4 \mathrm{~b}$ 환, $6 \mathrm{a}$ 환이 강한 전형적인 $\mathrm{A}$ 도형의 특징을 나타냈다. 건식제분 쌀가루는 습식제분 쌀가루보다 회절강도가 더 높게 나타났고, 특히 amylose-lipid complex 특징을 나타내는 회절각도 $23^{\circ}$ 근처 의 peak도 건식제분 쌀가루가 습식제분 쌀가루보다 회절강 도가 더 높게 나타났다. 이와 같은 특징은 지방산이 amylose 와 결합하여 전분분자의 용해도를 감소시키는 요인으로

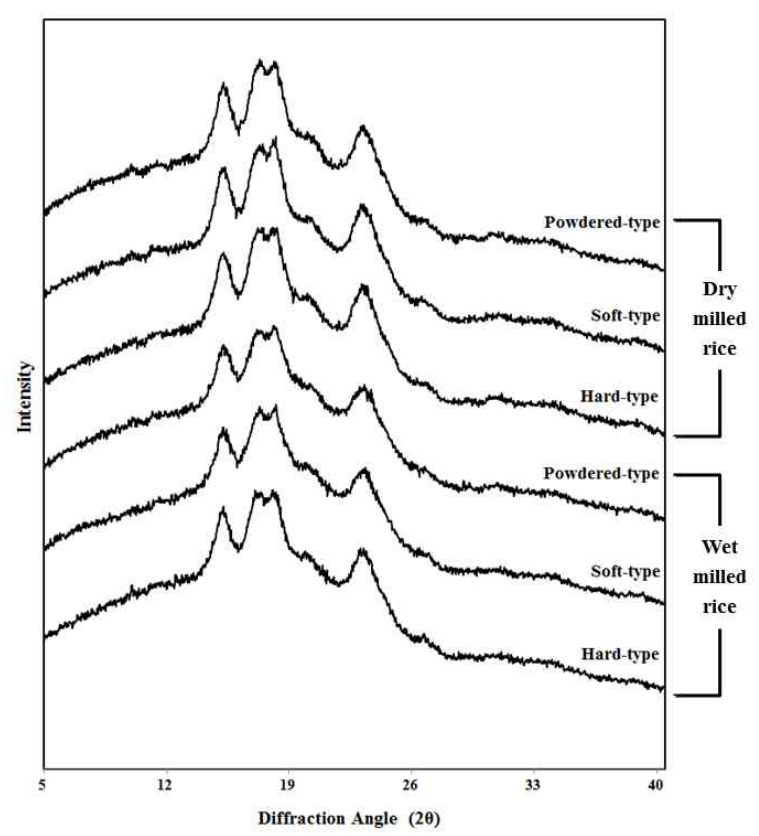

Fig. 2. X-ray diffraction patterns of the different types of rice flour using different grinding methods. 
작용한다. Table 3의 결과에서 amylose-lipid complex가 더 큰 건식제분 쌀가루는 습식제분 쌀가루보다 용해도가 낮은 것을 확인할 수 있다. 한편 분질, 연질, 경질미 쌀가루 종류 에 따른 X-선 회절도의 차이점은 거의 나타나지 않았다.

\section{Amylogram에 의한 호화 특성}

건식 및 습식 제분한 분질, 연질, 경질미 쌀가루의 amylogram에 의한 호화 특성을 측정한 결과는 Table 4 와 같다. 쌀가루의 호화개시온도 측정 결과, 건식제분 쌀가루 는 $65.44 \sim 68.62^{\circ} \mathrm{C}$ 로 나타났고 습식제분 쌀가루는 64.02 $\sim 68.20^{\circ} \mathrm{C}$ 으로 나타났으며, 건식제분 연질미 쌀가루에서 $68.62^{\circ} \mathrm{C}$ 에서 가장 높았고 습식제분 분질미 쌀가루에서 $64.02^{\circ} \mathrm{C}$ 로 가장 낮았으며, 호화개시온도 범위는 건식제분 한 쌀가루가 습식제분 쌀가루보다 더 높게 나타났다. 건식 제분 쌀가루의 최고점도는 397.00 427.00 B.U로 나타났고 습식제분 쌀가루는 504.40 627.60 B.U로 나타났으며, 습식 제분 연질미 쌀가루가 627.60 B.U로 가장 높았고 건식제분 연질미 쌀가루가 397.00 B.U로 가장 낮았다. 건식제분 쌀가 루보다 습식제분 쌀가루의 최고점도가 증가하는 것은 수침 과정 중 단백질과 지방 성분의 손실로 상대적으로 전분질 함량이 높아지기 때문이라고 할 수 있다(30). 최고점도시 온도를 측정한 결과, 건식제분 쌀가루는 $86.78 ~ 89.76^{\circ} \mathrm{C}$ 이었 고 습식제분 쌀가루는 $87.68 \sim 88.30^{\circ} \mathrm{C}$ 로 나타났고, 최고온도 시 점도 측정 결과, 건식제분 쌀가루는 303.00 317.40 B.U 이었고 습식제분 쌀가루는 344.20 437.80 B.U로 나타났다. 최저점도 측정 결과, 건식제분 쌀가루는 174.60 206.80 B.U 이었고 습식제분 쌀가루는 225.60 263.20 B.U로 나타났으 며, $50^{\circ} \mathrm{C}$ 에서 냉각점도를 측정한 결과, 건식제분 쌀가루는 379.00 422.20 B.U이었고, 습식제분 쌀가루는 425.40 492.60 B.U로 나타나, 최저점도와 냉각점도는 습식제분 연 질미 쌀가루가 가장 높은 반면, 건식제분 연질미 쌀가루는 가장 낮았다. Breakdown에서 건식제분 쌀가루는 220.40 232.20 B.U이었고, 습식제분 쌀가루는 279.00 364.20
B.U 이었으며, setback에서 건식제분 쌀가루는 202.20 212.80 B.U이었고, 습식제분 쌀가루는 197.80 227.00으로 나타났다. Breakdown과 setback에서는 습식제분 연질미 쌀 가루가 가장 높았고, 건식제분 분질미 쌀가루는 breakdown 이 가장 낮았으며, 습식제분 분질미 쌀가루는 setback이 가 장 낮았다. Amylogram에 의해 측정한 건식제분과 습식제 분 쌀가루는 모든 항목에서 시료간에 유의한 차이가 있었 고, 최고점도, 최고온도시 점도, 최저점도, 냉각점도 및 breakdown은 습식제분 쌀가루가 건식제분한 쌀가루보다 더 높았다. 분질미 쌀가루는 최고점도, 최고온도시 점도, 최저점도, 냉각점도 및 breakdown에서 건식제분과 습식제 분의 차이가 가장 적은 것으로 나타나, 쌀 관련 가공제품을 제조시 분질미의 경우 비용이 적게 소요되는 건식제분 방법 으로 분쇄한 쌀가루 이용도 괜찮을 것으로 생각된다. 연질 미의 경우 건식제분과 습식제분 방법에 따라 가장 큰 차이 를 나타냈고, 특히 최고점도, 최소점도, 냉각점도 및 setback 은 건식제분에서 가장 낮았으나 습식제분에서는 가장 높은 값을 보여 제분방법에 의해 큰 영향을 받는 것을 확인할 수 있었다.

\section{시차열량주사계에 의한 호화 특성}

건식 및 습식 제분한 분질, 연질, 경질미 쌀가루를 시차열 량주사계에 의한 호화 특성을 측정한 결과는 Table 5와 같다. 쌀가루의 호화개시온도 측정 결과, 건식제분 쌀가루 는 $62.84 \sim 66.09^{\circ} \mathrm{C}$ 로 나타났고 습식제분 쌀가루는 $60.54 \sim$ $63.51^{\circ} \mathrm{C}$ 으로 나타났고, 건식제분 연질미 쌀가루가 $66.09^{\circ} \mathrm{C}$ 에서 가장 높았으며 습식제분 분질미 쌀가루는 $60.54^{\circ} \mathrm{C}$ 로 가장 낮았다. 쌀가루의 호화정점온도 측정 결과, 건식제분 쌀가루는 $69.49 \sim 74.06^{\circ} \mathrm{C}$ 로 나타났고 습식제분 쌀가루는 $68.27 \sim 72.50^{\circ} \mathrm{C}$ 으로 나타났고, 건식제분 연질미 쌀가루가 $74.06^{\circ} \mathrm{C}$ 에서 가장 높았으며 습식제분 분질미 쌀가루는 $68.27^{\circ} \mathrm{C}$ 로 가장 낮았다. 쌀가루의 호화종료온도 측정 결과, 건식제분 쌀가루는 $75.26 ~ 80.60^{\circ} \mathrm{C}$ 로 나타났고 습식제분 쌀

Table 4. Amylogram properties of the different types of rice flour using different grinding methods

\begin{tabular}{lccc|ccc}
\hline \multirow{2}{*}{ Samples } & \multicolumn{3}{c|}{ Dry milled rice } & \multicolumn{3}{c}{ Wet milled rice } \\
\cline { 2 - 7 } & Powdered type & Soft type & Hard type & Powdered type & Soft type & Hard type \\
\hline Initial pasting temp. ${ }^{\circ}$ C) & $65.44 \pm 0.84^{\mathrm{cl} l)}$ & $68.62 \pm 0.31^{\mathrm{a}}$ & $67.00 \pm 0.52^{\mathrm{b}}$ & $64.02 \pm 0.88^{\mathrm{d}}$ & $68.20 \pm 0.45^{\mathrm{a}}$ & $66.12 \pm 0.73^{\mathrm{c}}$ \\
Maximum viscosity (B.U.): P & $427.00 \pm 8.57^{\mathrm{d}}$ & $397.00 \pm 5.24^{\mathrm{e}}$ & $419.00 \pm 15.94^{\mathrm{d}}$ & $504.40 \pm 6.58^{\mathrm{c}}$ & $627.60 \pm 4.77^{\mathrm{a}}$ & $582.00 \pm 3.74^{\mathrm{b}}$ \\
Temp. at maximum viscosity ( $\left.{ }^{\circ} \mathrm{C}\right)$ & $86.78 \pm 1.45^{\mathrm{c}}$ & $89.76 \pm 1.04^{\mathrm{a}}$ & $88.72 \pm 1.16^{\mathrm{ab}}$ & $87.94 \pm 0.78^{\mathrm{bc}}$ & $87.68 \pm 0.72^{\mathrm{bc}}$ & $88.30 \pm 0.77^{\mathrm{b}}$ \\
Viscosity at $95^{\circ}$ C(B.U.) & $303.00 \pm 4.30^{\mathrm{e}}$ & $304.60 \pm 7.50^{\mathrm{e}}$ & $317.40 \pm 3.78^{\mathrm{d}}$ & $344.20 \pm 1.64^{\mathrm{c}}$ & $437.80 \pm 11.03^{\mathrm{a}}$ & $410.80 \pm 8.17^{\mathrm{b}}$ \\
Minimum viscosity (B.U.): H & $206.80 \pm 6.57^{\mathrm{d}}$ & $174.60 \pm 3.91^{\mathrm{f}}$ & $187.20 \pm 4.97^{\mathrm{e}}$ & $225.60 \pm 2.61^{\mathrm{c}}$ & $263.20 \pm 3.11^{\mathrm{a}}$ & $246.60 \pm 1.95^{\mathrm{b}}$ \\
Viscosity at $50^{\circ}$ C(B.U.): C & $422.20 \pm 6.98^{\mathrm{c}}$ & $379.00 \pm 4.85^{\mathrm{e}}$ & $397.20 \pm 4.38^{\mathrm{d}}$ & $425.40 \pm 2.07^{\mathrm{c}}$ & $492.60 \pm 4.34^{\mathrm{a}}$ & $459.80 \pm 3.27^{\mathrm{b}}$ \\
Breakdown: P-H & $220.40 \pm 7.96^{\mathrm{e}}$ & $222.00 \pm 3.46^{\mathrm{de}}$ & $232.20 \pm 13.68^{\mathrm{d}}$ & $279.00 \pm 7.97^{\mathrm{c}}$ & $364.20 \pm 6.61^{\mathrm{a}}$ & $335.20 \pm 4.76^{\mathrm{b}}$ \\
Setback: C-H & $212.80 \pm 3.42^{\mathrm{b}}$ & $202.20 \pm 4.32^{\mathrm{d}}$ & $207.60 \pm 1.95^{\mathrm{c}}$ & $197.80 \pm 0.84^{\mathrm{e}}$ & $227.00 \pm 3.16^{\mathrm{a}}$ & $211.00 \pm 1.87^{\mathrm{bc}}$ \\
\hline
\end{tabular}

${ }^{1)}$ All the values are mean $\pm \mathrm{SD}$, means with different superscripts in a column significantly differed $(\mathrm{p}<0.05)$ in Duncan's multiple-range test. 
가루는 $74.53 \sim 79.80^{\circ} \mathrm{C}$ 으로 나타났으며, 건식제분 연질미 쌀가루가 $80.60^{\circ} \mathrm{C}$ 에서 가장 높았고 습식제분 분질미 쌀가 루는 $74.53^{\circ} \mathrm{C}$ 로 가장 낮았다. 따라서 호화개시온도, 호화정 점온도, 호화종료온도는 건식제분 쌀가루가 습식제분 쌀가 루에 비해 높게 나타났고 연질, 경질, 분질미 쌀가루 순으로 호화온도가 높았는데 Table 4의 amylogram 초기호화온도 결과와 같은 경향이다. 호화엔탈피는 습식제분 경질미 쌀 가루가 $2.50 \mathrm{cal} / \mathrm{g}$ 으로 가장 높았고, 건식제분 연질미 쌀가 루는 $1.71 \mathrm{cal} / \mathrm{g}$ 으로 가장 낮은 것으로 나타났다. 습식제분 한 쌀가루의 호화엔탈피가 건식제분한 쌀가루의 호화엔탈 피 보다 높은 것으로 나타났으며, 시차열량주사계에 의한 호화 특성 모든 항목은 시료간에 유의한 차이가 있었다. 전분의 손상 정도가 클수록 호화엔탈피가 낮게 나타나는 것으로 알려져 있는데(31), 건식제분 연질미 쌀가루의 호화 엔탈피가 가장 낮게 나타나 전분을 구성하는 분자 구조간의 결합력과 결정성이 낮은 것으로 확인되었으며, 건식제분과 습식제분의 호화엔탈피 차이가 가장 큰 것으로 나타나 건식 제분 방법으로의 활용도는 낮을 것으로 생각된다. 습식제 분 경질미 쌀가루의 호화엔탈피가 가장 높아 전분 결합력과 결정성이 높아 경질미를 분말화하여 가공제품에 활용한다 면 습식제분하여 이용하는 것이 좋을 것으로 생각된다. 분 질미 쌀가루의 경우 amylogram에 의한 호화 특성 분석과 유사하게 건식제분과 습식제분을 비교했을 때 호화엔탈피 차이가 적은 것으로 나타나 제분방법에 따른 안정성이 가장 좋은 것으로 생각된다.

Table 5. Differential scanning calorimeter (DSC) thermal properties of the different types of rice flour using different grinding methods

\begin{tabular}{cccccc}
\hline & Samples & $\begin{array}{c}\text { Onset } \\
\text { temperature } \\
\left({ }^{\circ} \mathrm{C}\right)\end{array}$ & $\begin{array}{c}\text { Peak } \\
\text { temperature } \\
\left({ }^{\circ} \mathrm{C}\right)\end{array}$ & $\begin{array}{c}\text { End } \\
\text { temperature } \\
\left({ }^{\circ} \mathrm{C}\right)\end{array}$ & $\Delta \mathrm{H}(\mathrm{cal} / \mathrm{g})$ \\
\hline $\begin{array}{c}\text { Dry } \\
\text { milled } \\
\text { rice }\end{array}$ & $\begin{array}{c}\text { Powdered type } \\
\text { Soft type }\end{array}$ & $62.84 \pm 0.20^{\mathrm{dl})}$ & $69.49 \pm 0.15^{\mathrm{e}}$ & $75.26 \pm 0.20^{\mathrm{e}}$ & $2.05 \pm 0.12^{\mathrm{c}}$ \\
& Hard type & $64.35 \pm 0.09 \pm 0.22^{\mathrm{a}}$ & $74.06 \pm 0.19^{\mathrm{a}}$ & $80.60 \pm 0.64^{\mathrm{a}}$ & $1.71 \pm 0.13^{\mathrm{d}}$ \\
\multirow{2}{*}{$\begin{array}{c}\text { Wet } \\
\text { milled } \\
\text { rice }\end{array}$} & $\begin{array}{c}\text { Powdered type } \\
\text { Soft type }\end{array}$ & $60.54 \pm 0.20^{\mathrm{f}}$ & $68.27 \pm 0.12^{\mathrm{f}}$ & $74.53 \pm 0.40^{\mathrm{f}}$ & $2.16 \pm 0.15^{\mathrm{bc}}$ \\
\hline
\end{tabular}

${ }^{11}$ All the values are mean $\pm \mathrm{SD}$, means with different superscripts in a column significantly differed $(p<0.05)$ in Duncan's multiple-range test.

\section{요 약}

가공용 쌀 품종으로 개발된 분질미, 연질미, 경질미의 쌀 가공제품 이용 가능성과 활용도를 알아보기 위하여 이화 학적 특성 및 호화특성을 분석한 결과는 다음과 같다. 일반 성분 분석결과, 건식제분 쌀가루의 수분함량은 7.68
$7.99 \%$, 습식제분 쌀가루는 7.03 7.57\% 이었고, 조단백 함량 은 건식제분 쌀가루에서 7.96 8.35\%, 습식제분 쌀가루에서 7.94 8.12\% 이었다. 조지방 함량은 건식제분 쌀가루에서 $1.32 \sim 1.49 \%$, 습식제분 쌀가루에서 $0.71 \sim 0.99 \%$ 이었고, 조회 분 함량은 건식제분 쌀가루에서 $0.71 \sim 0.82 \%$, 습식제분 쌀 가루에서 $0.25 ~ 0.31 \%$ 이었다. 백색도 측정 결과, 습식제분 분질미 쌀가루에서 96.40 으로 가장 높게 나타났고 건식제 분 연질미 쌀가루에서 95.63으로 가장 낮게 나타났다. 적색 도 측정 결과, 건식제분 분질미 쌀가루는 -0.37 로 가장 높았고 습식제분 경질미 쌀가루는 -0.65 로 가장 낮게 나타 났다. 황색도 측정 결과, 건식제분 경질미 쌀가루는 3.46 으 로 가장 높았고 습식제분 분질미 쌀가루에서 2.59 로 가장 낮게 나타났다. 주사전자현미경을 이용한 입자의 형태를 관찰한 결과, 모든 시료에서 쌀 전분 특유의 입자 형태를 보였고, 건식제분 쌀가루가 불규칙하고 거칠며 큰 입자가 많은 것으로 나타났다. 수분흡수지수와 수분용해지수는 습 식제분 연질미와 경질미 쌀가루가 높았고, 건식제분 분질 미가 가장 낮았다. X-선 회절도 분석결과, 모든 시료는 전형 적인 A 도형의 특징을 나타냈고, 건식제분 쌀가루의 회절강 도가 높게 나타났다. Amylogram에 의한 호화 특성 분석 결과, 습식제분한 연질미 쌀가루는 최고점도, breakdown, setback에서 가장 높게 나타났고, 건식제분한 연질미 쌀가 루는 호화개시온도에서 가장 높았으나 최고점도와 breakdown 에서는 가장 낮았다. 습식제분한 경질미 쌀가루는 호화개 시온도와 setback에서 가장 낮았다. 시차열량주사계에 의한 호화 특성 분석 결과, 건식제분한 연질미 쌀가루는 호화개 시온도, 호화정점온도, 호화종료 온도에서 가장 높았으나 호화엔탈피는 가장 낮았다. 따라서 분질미 쌀 품종은 건식 및 습식제분에서도 안정성이 높게 나타나 손상 전분이 적어 쌀 가공제품에 활용도가 높을 것으로 생각된다.

\section{감사의 글}

본 연구는 농촌진흥청 및 전남농업기술원의 연구비 지원 으로 수행된 연구 결과의 일부로 이에 감사드립니다.

\section{References}

1. Jun HI, Yang EJ, Kim YS, Song GS (2008) Effect of dry and wet millings on physicochemical properties of black rice flours. J Korean Soc Food Sci Nutr, 37, 900-907

2. Lee MK, Shin M (2006) Characteristics of rice flours prepared by moisture-heat treatment. Korean J Food Cookery Sci, 22, 147-157 
3. Kwak TS (2011) Varietal variation of grain yield and physico-chemical properties related to grain quality of the major rice varieties by the released year. Korean $\mathrm{J}$ Intl Agri, 23, 109-114

4. Chae JC (2004) Present situation, research and prospect of rice quality and bioactivity in Korean. Food Sci Industry, 37, 47-54

5. Yang CI, Choi YH, Lee SB, Lee KS, Lee JH, Hong HC, Kim HY, Shin YS, Hwang HG, Yang SJ, Jung OY, Jeon YH, Oh MG, Kim MK, Lee JH, Cho YC, Lee JI, Hwang KH, Kim YG, Lee YT (2012) A new black pericarp and processing soft rice cultivar 'Heuseol'. Korean J Breed Sci, 44, 35-40

6. Kum JS (2010) Nutrition of rice and rice processing food. Food Preserv Processing Industry, 9, 38-54

7. Kim RY, Park JH, Kim CS (2011) Effects of enzyme treatment in steeping process on physicochemical properties of wet-milled rice flour. J Korean Soc Food Sci Nutr, 40, 1300-1306

8. Park YK, Seog HM, Nam YJ, Shin DH (1988) Physicochemical properties of various milled rice flours. Korean J Food Sci Technol, 20, 504-510

9. Choi BK, Kum JS, Lee HY, Park JD (2006) Physicochemical properties of black rice flours (BRFs) affected by milling conditions. Korean J Food Sci Technol, 38, 751-755

10. Park JD, Choi BK, Kum JS, Lee HY (2006) Physicochemical properties of brown rice flours produced under different drying and milling conditions. Korean J Food Sci Technol, 38, 495-500

11. Kim DW, Eun JB, Rhee CO (1998) Cooking conditions and textural changes of cooked rice added with black rice. Korean J Food Sci Technol, 30, 562-568

12. Lee YH, Kum JS, Ku KH, Chun HS, Kim WJ (2001) Changes in chemical compostion of glutinous rice during steeping and quality properties of Yukwa. Korean J Food Sci Technol, 33, 737-744

13. Lee MK, Kim JO, Shin MS (2004) Properties of nonwaxy rice flours with different soaking time and particle sizes. Korean J Food Sci Technol, 36, 268-275

14. Kim KJ, Pyun YR, Cho EK, Lee SK, Kim SK (1984) Kinetic studies o hydration of Akibare and Milyang 23 brown rice. Korean J Food Sci Technol, 16, 297-302

15. Kim SK, Bang JB (1996) Physicochemical properties of rice affected by steeping conditions. Korean J Food Sci Technol, 28, 1026-1032

16. Kim RY, Kim CS, Kim HI (2009) Physicochemical properties of non-waxy rice flour affected by grinding methods and steeping times. J Korean Soc Food Nutr, 38, 1076-1083

17. AOAC (1984) Official methods Analysis 14th ed. Associations of official analytical chemists. Washington DC, p 31-47

18. Anderson RA (1982) Water absorption and solubility and amylograph characteristics of roll-cooked small grain products. Cereal Chem, 59, 265-269

19. Medcalf DG, Gilles KA (1966) Effect of a lyotropic ion series on the pasting characteristics of wheat and corn starches. Starch, 18, 101-105

20. Donovan JW, Lorenz K, Kulp K (1983) Differential scanning calorimetry of heat-moisture treated wheat and potato starches. Cereal Chem, 60, 381-387

21. Lee SH, Shin M (2009) Characteristics of preparation of rice manju and rice flour with soaking and different particle sizes. Korean J Food Cookery Sci, 25, 427-434

22. Chen JJ, Lu S, Lii CY (1999) Effect of milling on the physicochemical characteristics of waxy rice in Taiwan. Cereal Chem, 76, 796-799

23. Chiang PY, Yeh AI (2002) Effect of soaking on wet-milling of rice. J Cereal Sci, 35, 85-94

24. Kim K, Lee YH, Kang KJ, Kim SK (1993) Effects of steeping on physicochemical properties of waxy rice. Korean J Food Sci, 25, 535-540

25. Lee MG, Shin MS (2006) Characteristics of rice flour prepared by moisture-heat treatment. Korean J Food Cookery Sci, 22, 147-157

26. Kum JS, Lee SH, Lee HY, Kim KH, Kim YI (1993) Effect of different milling methods on distribution of particle size of rice flours. Korean J Food Sci Technol, 25, 541-545

27. Anjum FM, Walker CE (1991) Review on the significance of starch and protein to wheat kernel hardness. J Sci Food Agric, 56, 1-13

28. Kim SS, Kang KA, Choi SY, Lee YT (2005) Effect of elevated steeping temperature on properties of wet-milled rice flour. J Korean Soc Food Sci Nutr, 34, 414-419

29. Bean MM, Effliston-Hoops EA, Nishita KD (1983) Rice flour treatment for cake-baking application. Cereal Chem, $6,445-449$

30. Kum JS, Lee HY (1999) The effect of the varieties and particle size on the properties of rice flours. Korean $\mathbf{J}$ Food Sci Technol, 31, 1542-1548

31. Kum JS, Lee SH, Lee HY, Kim KH, Kim YI (1993) Effects of different milling methods on physico-chemical properties and products. Korean J Food Sci Technol, 25, 546-551 